\title{
Article \\ Durendal, translated: Islamic object genealogies in the chansons de geste
}

\author{
Shirin A. Khanmohamadi \\ Department of Comparative and World Literature, San Francisco State University, \\ San Francisco, CA, USA.
}

\begin{abstract}
The transfer of Saracen arms into Frankish ownership is a leitmotif of many chansons de geste, but one whose significance for translatio imperii has yet to be elucidated. In this essay, I focus on the Chanson d'Aspremont, a twelfth-century epic set in Calabria that narrates the pre-history of Durendal, Roland's sword of Song of Roland fame, as an object inherited by Roland from its former royal Muslim owner. Drawing on cultural history and a number of object-translation models derived from material and spolia studies, I read the sword's symbolic transfer as evidence of Norman desire for and appropriation of former Fatimid imperium in Sicily.
\end{abstract}

postmedieval: a journal of medieval cultural studies (2017). 8, 321-333. doi:10.1057/s41280-017-0061-3

Medievalists working in language and literature departments recognize words like 'renovation', 'appropriation', 'supersession,' and 'homage' as proper to the trope of translatio studii and the complex recontextualization of borrowed literary materials that it describes, but what may be less known to them is that much the same language is being used by art historians analyzing the cultural work of material artifacts that combine objects from multiple traditions and/or chronologies (see Hansen, 2003; Walker, 2012). One reason that the use of the trope of translatio in material culture studies might surprise literary critics is 
1 For a recent treatment of relic translation as a form of translatio imperii, see Perry (2015).

2 For an overview of medieval translatio/n studies, see Campbell and Mills (2012, 1-20). The medieval translatio topos combines transfers of power, learning, relics, and text, 'without [...] opposition between the literal and the figural meanings' (Stahuljak, 2004, 38 ), i.e. between objects and texts. Translatio imperii and translatio studii appeared in the ninth century, becoming increasingly coordinated in the later Middle Ages (Stahuljak, 2005, 144-145).

3 The title of the final section of the 2009 issue, 'Lost in Translation?’

4 But see Wacks (2014) for synonymous treatment of relics and other objects and texts, and Akbari (2012, 2014) on how bodies and monuments symbolically signal translatio imperii in siege poetry and chronicles. that medieval literary studies have thus far been slow to recognize the movement of objects (with the notable exception of relics) ${ }^{1}$ as part of the complex dynamics of translatio imperii et studii or the movement of universal empire and learning. ${ }^{2}$

The Medieval Translator, devoted to the topic of translatio/n, only recently moved 'beyond translation'3 to consider of the translatio of non-textual materials, including images and artifacts (Renevey and Whitehead, 2009), while literary analyses that have effected a 'material turn' in tracing the movement of objects in order to display the appropriative and emulative selffashioning of rival medieval empires have stopped short of deploying the term 'translatio' in their descriptions of these cross-cultural and inter-imperial dynamics (Burns, 2002; Kinoshita, 2012). ${ }^{4}$ Literary critics have, moreover and no doubt relatedly, been slow to recognize and fully marshal the utility of emerging models of object translation within art history and material culture studies for literary studies, models for rethinking such germane questions as how recontextualized art objects 'accumulate' rather than supersede past meanings in new contexts (Forsyth, 1995), or how object transfers create networks of affiliation and homage between parties - individual, institutional, imperial, cultural - to an object exchange (Buc, 1997). While some of these object translation models 'think across' the object-literature boundary by treating objects as symbols of power and complex social relations legible in the manner of texts (Forsyth, 1995; Hansen, 2003; Flood, 2009), others follow more recent interdisciplinary posthumanist trends in interrogating the human-non-human boundary to show the 'mutual imbrications' of animate subjects and inanimate objects (Flood, 2009, 12; Buc, 1997), ${ }^{5}$ and, by implication, of their study. The impact and negotiation of these posthumanist trends together with the recent 'material turn' of the new medievalism (see Block et al., 2014) have made premodern literary study, for its part, ever more open to the investigation of literature through extra-literary models. ${ }^{6}$

This essay advances its own material turn on the traditionally linguistic delimitation of the trope of translatio imperii et studii, first by enfolding the spatial movement or translation of secular objects into the trope's operation, and then by deploying models of 'object translation' drawn from recent spolia and material culture studies to interpret the meanings of those translated objects. My focus is on a set of object transfers commonly found in high medieval Old French chansons de geste and their later vernacular translations: the transfer of swords and other personal war effects from Arab to Frankish hands. I take as my primary example the Chanson d'Aspremont, a twelfth-century Charlemagne-cycle epic of southern Italian provenance that plots a royal Muslim pre-history for one of the most famous swords of all medieval literature, Roland's Durendal (see La Chanson de Roland, 1922). ${ }^{7}$ In her ground-breaking book Medieval Boundaries, Sharon Kinoshita suggests the power of literary objects such 
as the (translationally overdetermined) Trojan cup ${ }^{8}$ of Floire et Blancheflor to unsettle governing critical assumptions about both the theory and practice of translatio imperii et studii and interconfessional relations in the medieval Mediterranean (Kinoshita, 2006, 77-104). ${ }^{9}$ The movement of Durendal in the Chanson d'Aspremont similarly unsettles critical understandings of the nature of Islamic-Christian relations in the medieval period, still dominated by the narrative of the crusades, as well as of the practice of translatio imperii et studii, but does so, notably, within the genre of epic: a genre rarely considered in relation to medieval ideas of universal monarchy or its movement (but see Sunderland, 2012), whose pervasive Saracens are rarely regarded as something other than the enemy foils of European civilization. Against these critical expectations, the Chanson d'Aspremont forges a mode of translatio imperii that genealogically grafts European imperial authority not to the Greco-Roman imperial past, but to the Islamic one.

As a Charlemagne-cycle epic set and likely composed in Italy, the Chanson d'Aspremont, which survives in six manuscripts and numerous fragments, forms part of the diverse corpus of the 'French of Italy,' vernacular texts composed or copied in French or Franco-Italian for Francophone and Italian audiences in Italy from the twelfth to the fifteenth century (see French of Italy, 2017). It is, then, a work of translation in more than one way. As a text set in a Calabria and Sicily that Charlemagne must defend against Saracen incursion, it reflects the translation of Carolingian legends and the matter of France into an Italian context, i.e. translatio studii traditionally conceived, and endeavors (along with other Italian translations of the matter of France) to provide the Italian prequel or 'antefatto' to the famed events and characters of the Chanson de Roland (Everson, 2001). But the Chanson d'Aspremont at once narrates another, material form of translatio: the translation of Roland's personal war effects of Song of Roland fame - his sword Durendal, his horse Veillantif, and his oliphant - from royal Muslim hands into the hands of Roland himself. Indeed, Durendal is invoked in the opening lines of the Aspremont, those announcing the matter of the song's geste, forecasting its central role in the epic (Aspremont, 14-15). ${ }^{10}$

But why should these object transfers be so central? What political and cultural work are they effecting for Roland, Charles, or the French (or Italians thinking about Roland, Charles, or the French from a southern Italian horizon), and why do they all come from the enemy Arabs? The theme of transfers of swords and other war objects from Saracen to Frankish hands in Old French and other vernacular epics has certainly not escaped critical attention. A generation ago Paul Bancourt took note of it in his magisterial study of the matter of the Saracens in the Charlemagne cycle, Les Musulman dans les chansons de geste du
5 Flood describes how the Islamic khil'a or honorific robe finds circulation as 'part of the donor' himself in a gift economy (2009, 76-77).

6 See Chaganti (2008) for an early use of material culture, in this case reliquaries, to read late medieval English texts.

7 This is not the only Muslim genealogy of Durendal in Carolingian epic: in Mainet, Durendal is stripped off the body of the Saracen Braimant by Charlemagne himself.

8 Virgil's Aeneid instantiates a celebrated example of translatio imperii in Aeneas' translation of his 'household gods' from Troy to Latium; it is by way of Troy that many European royal houses traced their lineage to the classical world. See Virgil (1983, 1.10-11, 93-94) and Waswo (1995). 
9 The study of material culture has been at the forefront of mapping unexpected crossconfessional turns in the medieval Mediterranean; see Grabar (1997), Georgopoulou (1999), Hoffman (2001), Kinoshita (2004), and Shalem (2004).

10 I use Brandin's (1919) edition of Aspremont, based on the Wallaton Hall MS and translations by Newth (1989). Line numbers are the same for both texts.

11 Among the chansons de geste featuring swords translated from Saracens are Aspremont, Fierebras, Huon de Bordeaux, Saisnes, Chevalerie d'Ogier, Prise d'Orange, Narbonnais, Elie de Saint-Gilles, and Mainet. cycle du roi (Bancourt, 1982, 947-950). ${ }^{11}$ There Bancourt attributed the trend to the high market value of such technologically advanced, beautifully made Arab swords, a reading that collapses the circulation and value of Arab war objects within texts with their circulation outside the text in the world. The Chanson d'Aspremont is in fact strikingly concerned, perhaps even preoccupied, with the transfer of beautiful spoils of war from Muslim to Frankish lines in a way that does suggest worldly desire, and leaves no doubt as to the economic value of waging effective war from the standpoint of the victor. But the chansons are imaginative media and surely Roland's war effects are worth something more than, or other than, their weight in gold; they bear symbolic and political value.

To assess the nature of these values, we can start by looking at the precise nature of the powers of Durendal and the oliphant in the Song of Aspremont. At the start of the chanson, these objects are in the possession of Aumon, son of the Saracen Emir Agolant, ruler of both Africa and Asia. In a pivotal episode in the text, Charles and Aumon share a dramatic battle, the most significant one for Charles in the epic, which ends with the boy Roland coming to Charles' rescue, killing Aumon and assuming proper knighthood through possession of his first sword, Durendal, together with Aumon's horse and oliphant. Roland is needed to intercede in this encounter precisely because the martial powers of Charles and Aumon, or more precisely the powers of their armor, are so evenly matched. Durendal is unstoppable: 'Nes puet garir ne elmes ne claviel' ['no chain-mail coat or helmet can withstand him'] (3283), the singer tells us, and 'cui il consuit de sa vie est nïant' ['the man he strikes knows that his life is spent'] (4754). It has to be: 'Durendals trence trop malement' ['Durendal has too evil an edge'] (4757). While the poet also tells us, 'se rois Eaumes puet vivre longuement, / soie estra France, se Dex ne l'en desfent' ['If King Aumon lives on for any length / he will have France, unless Lord God prevents (it)'] (4758-4759), it is actually Aumon's blade that will conquer France unless despoiled of its owner (hence, flashing forward to the Chanson de Roland, Roland's attempt to destroy the blade rather than let it return to Saracen hands). But Charles is outfitted with an equally remarkable and undefeatable helmet, one protected by God and bearing a sacred, ancient stone; it is inviolable even to Durendal's throws. Aumon must literally peel Charles' helmet off his head if he is to prevail, and this is just what he does, on point of defeating Charles but for Roland's intrusion in the scene. So long as Charles wears his sacred helmet, he is under its protection; so long as Durendal is wielded, its wielder is victorious - these objects have laws and powers of their own.

Similarly, the Aspremont's construction of the oliphant endows it with hidden powers, but these can be glimpsed only in comparison with Chanson de Roland, the narrative of which Aspremont aims to prefigure. For the oliphant, famously sounded too late in the Roland, will not sound off in a timely manner in Aumon's hands either: Aumon likewise waits too long, is too proud to call for 
help until it is too late, and in short displays precisely the pride and epic démesure that transfer to Roland - along with the oliphant itself - in the Chanson de Roland. Thus in the Aspremont, objects of war display power and even personality in their uncanny ability to shape the destiny of their owners, whose fate is bound up closely with their own. How best can we understand these powers and from whence they derive? While Charles' helmet bears 'un tel piere que Dex ot tant amee' ['a wondrous jewel touched by God's hand in blessing'] (Aspremont, 5932) and 'pieres i ot des le tans Jeremie' ['sacred stones first cut / in Jeremiah's time'] (Aspremont, 5907; Newth, 5907-5908), Aumon is a pagan and we must look elsewhere for the sources of Durendal's power.

Here we can fruitfully turn to Patrick Geary's cultural history on the ideology of swords and sword transfers (Geary, 1994). Drawing from Germanic and Icelandic sources, Geary offers a description that matches the work of swords in the Chanson d'Aspremont itself: ${ }^{12}$

The long sword [...] was a weapon of great importance in the migration period and the early Middle Ages. The techniques of manufacture and the great investment of scarce steel made the sword more than a weapon: it was a symbol of status and an object of magic. Its magical character was in fact one of its essential qualities; it had not only its own name [...] but its own personality as well. Its forces came from the otherworld $[\ldots]$ the fate of the user was attached to his sword in a mysterious and fatal way, and thus anyone able to acquire the sword thereby acquired the virtues of its previous owner. Small wonder then that the sword attained a privileged role as a symbol of legitimacy and continuity. (Geary, 1994, 61-62; my italics)

Geary then relates an eighth-century tale of a Lombard conqueror who opens the tomb of a past Lombard king and removes his sword, not as a form of despoiling the grave, but as a way of 'meeting with the dead king, and returning as his successor' (64). One is reminded in this connection of the politics of wielding Caliburn, Arthur's legendary sword, a native Welsh symbol reputedly possessed by Richard the Lion-heart in twelfth-century England, or of displaying Arthur's crown, as Edward I allegedly did in his thirteenth-century conquest of Wales (Gillingham, 2000; Knight, 2000). Swords, then, serve as symbols of the legitimate rule of their owners and as vehicles for the transfer of such legitimacy from past to new rulers, even and perhaps especially when the symbols of power being transferred are native ones and the new rulers wielding them are foreigners enacting conquest.

As objects ensuring legitimate succession, swords like Durendal and oliphants too (see Shalem, 2004, 88-97, 120-124) are doing 'translational work,' i.e. the work of legitimating the transfer of rightful dominion and authority from one group to another. That they do so within the chanson de geste genre is of note given our scholarly emphasis on the romance as the privileged site for the work
12 Indeed Geary makes the connection to the Carolingian context: 'Such accounts of entering tombs to claim swords [...] create parallels so great as to suggest a common culture' with Carolingian Europe (1994, $65)$. 
of translatio, but it should not otherwise surprise us: many chansons de geste feature contest over lands, borders, and empires; as borders shift, new rulers and empires require legitimization. In the context of twelfth-century Sicily and Calabria in which the Aspremont is set and was likely composed, the notion of a Frankish group benefiting from the legitimate transfer of authority from Arabs no doubt resonated with conditions within living memory, that is with the Norman conquest of Sicily and Calabria in the eleventh and twelfth centuries after some two centuries of Arab rule. Palermo and Sicily were conquered by the Normans under Roger I in 1091 CE, and the Kingdom of Sicily officially established under Roger II's rule in 1130 CE. The Normans had to convince the Muslims of Sicily to accept Christian overlords, a situation not seen anywhere previously in the Mediterranean (Catlos, 2015, 136). Originally pulled into the Sicilian orbit as mercenaries for hire by local Arab factions, Robert Guiscard and Roger I cannily portrayed the conquest of Sicily as vengeance for the inhabitants' killing of their ally and former ruler of Sicily, Ibn al-Thumna; Robert and Roger claimed their connection to Ibn al-Thumna as a means of legitimizing their succession. They also used Muslim soldiers to capture Salerno and Capua, and when the time came for Palermo to surrender, the brothers declared themselves malik and qumis / king and count of Sicily, and minted coins with the Muslim profession of faith on them in Arabic. Roger built an administrative class of Byzantines and Muslims, keeping records in Arabic and Greek. Roger II added Apulia and Calabria to these domains, and made the Egyptian Fatimids, former rulers of Sicily, his closest allies. In their exercise of 'soft power' over the Normans, the Fatimids introduced their own chancery and administrative culture to the Normans and conferred Islamic regalia upon Roger II, including a parasol (Persian: chatr) that would become an almost universal symbol of cosmopolitan power, displayed by popes, emperors, and caliphs alike (Catlos, 2015, 154; Flood, 2009, 74,76). Roger II welcomed these cultural updates, which allowed him to level the playing ground and to compete more effectively with his Islamic and Byzantine rivals in the Eastern Mediterranean (Catlos, 2015, 154-155).

In the context of Norman (French-speaking) rule over the Muslim inhabitants of Sicily and Calabria, the notion of a legitimizing transfer of sovereign authority in the form of a sword from an Arab prince to the best warrior of the Frankish king, then, performs some fairly unambiguous cultural work. Further, Aumon actually bequeaths his sword to Roland, noting that should he die in battle, Durendal deserves a master with the war-lust and martial prowess he observes in Roland: 'Se ço est voirs que ici soit mes jors, / Je proi Mahon, le mien dieu glorïos / Que Durendals li remagne a tos jors' ['And if today should mark my lifetime's ending / I pray Mahom, my great god, and request it / That this lad have my sword Durendal henceforth'] (6039-6041). Roland is marked by the epic, then, as the legitimate heir and successor of Durendal's powers, since claims of legitimate succession, however invented, are a major mode of 
articulating translatio imperii in medieval romance and chronicle writing (witness the multiple and competing genealogical links forged by so many European leaders with Trojan heroes, or with Charlemagne himself).

This no doubt still leaves a good deal unexplained: as Paul Bancourt noticed, the transfers of objects of war from Arab to Frankish hands extend well beyond a single chanson de geste or a single context like the multicultural Sicilian one, suggesting a greater and more diffuse phenomenon is at work. Here is where a turn to models of object translation developed within recent spolia studies is illuminating. 'Spolia' is a polysemous word with rich and wide-ranging applications: Latin for 'spoils' or 'anything "stripped" from someone or something,' the term was expanded to mean 'reused antiquities' in about $1500 \mathrm{CE}$. While in medieval Latin, spolia 'retains its classical, military meaning of "things taken by force," art historians today deploy the term to mean 'any artifact incorporated into a setting culturally or chronologically different from that of its creation' (Kinney, 2009, 233).

Recent studies of the use of spolia in medieval contexts suggest a cultural layering in which past cultural objects retain their meaning and specificity in a recontextualized present space, lending their cultural weight to the 'cumulative' meaning of the art work (Forsyth, 1995; Matthews, 2012; Ch'ien, 2016). Ilene Forsyth, for instance, has argued that tenth-century Ottonian art using concrete remains from highly diverse periods - ancient Roman, early Christian, Byzantine, Fatimid, Frankish, Anglo-Saxon, Merovingian, Carolingian, and early Ottonian - conveys a view of history that is 'Christian but cumulative, in the sense that earlier cultures, both pagan and Christian are subsumed within it' (Forsyth, 1995, 153). Notably, this 'accumulation' involves assimilation and supersession even as the past is 'given immediacy by being visibly embedded in the present' (Forsyth, 1995, 156) - supersession, that is, without erasure. The Ottonian perspective on the past, she avers, is thus less one of 'renovatio' than one of 'culminatio' (Forsyth, 1995, 158). Karen Matthews similarly notes of Andalusian spolia reused in Pisan churches in the eleventh and twelfth centuries that these Islamic objects 'did not lose their identity in their new Christian setting, but accrued additional meanings while preserving the origin of their memory,' one that evoked 'Muslim cultural sophistication and artistic prowess' (Matthews, 2012, 243-244). Such language of cultural 'accumulation' expressed in spolia echoes recent rethinking of the operation of translatio studii in the medieval Mediterranean. Tracing the desire to translate the Arabic fable collection Kalila wa Dimna across both eastern and western courts, from Persia to France, well into the late Middle Ages, Sharon Kinoshita has argued that these translation projects 'signified their patrons' royal or imperial pretensions' and are typical of the way in which premodern empires - Latin Christian, Islamic or Byzantine - sought to appropriate 'the cultural capital amassed by their predecessors' (Kinoshita, 2008, 381). 
13 Flood shows that Islamic honorific robes can function similarly 'as a kind of visual manifestation of an isnad,' or chain of authority $(2009$, $78)$.
A final example from spolia studies will bring us back to our text and our sword, and the full weight of the meaning of its transfer from Arab forebears. Phillipe Buc offers another layered and cumulative model of cultural translatio in his analysis of 'object-conversion,' a term he coins to detail the change in meaning undergone by secular or non-Christian objects upon their donation to a church. Although object-conversion involves elevation 'from a lesser to a superior domain' (Buc, 1997, 100), 'it is essential that the earlier identity still be recognizable,' and that 'the converted object should display its itinerary' or genealogy. Such open display is essential because object genealogies materialize a 'memorial network' (Buc, 1997, 127): in a political culture that remains, in the twelfth century, intensely personal, prestige and power are established through relationships and networks of relationships. An object's genealogy, in short, allows its new owner to express and establish a relationship of prestige and power by connection to the object's past owners. ${ }^{13}$ And in case we were not already thinking of Durendal, Buc likens the phenomenon to sword-genealogies attested in barbarian epics, offering the example of Charlemagne who 'obtained the swords of surrendering Saxon leaders inscribed with their names' (Buc, 1997, 101, n. 7). While critics might be tempted to read such submission of swords of the conquered as a clear sign of supersession and a voiding of old power before the new, analyses like Buc's cast a spotlight instead on the writing on these swords: names that establish genealogy, memorial networks, and inherited prestige and cultural capital for their new owners. The celebrated Song of Roland may be the vehicle that memorializes the legendary Durendal for its listeners, but the Song of Aspremont is the epic that inscribes Aumon's name upon that sword and so renders visible the network of power and prestige that Roland inherits along with it.

These cumulative models of translatio derived from spolia studies allow us to better approach the question with which I began, the prevalence of Arab or Saracen sword transfers in French and English epic: one need not have conquered a place (as did the Normans of Sicily, our Aspremont context) for political and cultural translatio to be at work - cumulative and aggregate transfer of cultural and political power requires only that a perceived prestige culture be involved in the chain of transfer. For all the language of civilizational opposition to which we have attended in the chansons de geste, there appears to coexist another, quite heterogeneous current of homage and desire for emulation of the Saracens. The latter moves the Saracens beyond their univocal status as Latin Christendom's enemies and upends any simple ideological reading of the epic.

Significantly, it is Durendal and not Joyeuse, Charles' sword, that is translated from Arab origins in the Aspremont. We may glimpse the great meaning and weight attributed to Joyeuse and its memorial network from another Charlemagne epic, the Mainet, a mid-twelfth-century Old French fragment that plots Charlemagne's boyhood adventures, namely his escape from ill-treatment by his 
half-brothers at French court and his taking refuge in the court of the Muslim emir of Toledo, where he is fostered and enters service as knight. ${ }^{14}$ Early in the story, Charles refuses a magnificent sword offered him by the emir, saying he prefers Joyeuse, which belonged to Clovis, the fifth-century Merovingian unifier of Frankish Gaul. Charles' refusal marks a dramatic turn in which the emir questions the birth of the young man who has recently come into his service. Thus sword and owner are again bound up together: Joyeuse reflects and casts light on the distinctiveness of Charles, and Charles does the same for Joyeuse. In setting both apart as distinct from their Islamic background, the Mainet thematizes the threshold and limit of Arab translatio in the epic. By having Charles distinguish himself by refusing an Arab sword for one derived from the Frankish dynasty preceding his own, the Mainet attests at once to the great, perceived seduction of the Arab sword and to the overwhelmingly powerful association - approaching taboo - that Charles would have invoked by carrying one. Joyeuse is the exception that proves the rule: the future renovator of European empire must carry a sword of European provenance; too much is being translated with this particular sword for it to be otherwise. This limit obtains in northern European epics and chronicles, although a turn to the thirteenth-century Spanish chronicle Primera crónica general, compiled during Alfonso X el Sabio's reign, reveals a 'Joyosa' that has in fact been translated to Charles from the Saracen king Bramante by way of Charles' enamored Toledan Saracen princess, Galiana (Grieve, 2009, 47).

Analysis of the translated objects of medieval epics through the lens of spolia studies allows us to unearth new literary histories that challenge long-held critical approaches to the chanson de geste, the matter of Saracens, and the work of translatio imperii et studii in medieval narratives. The work of objects in epics like the Chanson d'Aspremont opens up a view of the epic as a potential field of thinking and practice about Latin imperium and its sources, much like the chronicle and romance. The presence of such translational thinking within epic in turn recasts the epic as more open to ambiguity, contradiction and ambivalence that signature affect of translatio, as Rita Copeland has shown (1991) - than is usually credited. The tracing of war-object genealogies and their memorial networks within epic makes visible an alternative genealogy within translatio imperii - in the Aspremont, from contemporary Fatimid Muslim to Norman Sicilian possession - in which Latin Christian imperium anchors its authority and prestige not only in Greco-Roman sources but also in contemporary Islamic ones.

The insertion of the Saracens into the translation of empire in turn renders these ubiquitous figures of medieval epic and romance themselves more ambivalent, a source, at once, of Europeans' desires and fears, of expressions of homage and appropriation as well as supersession. As Zrinka Stahuljak has argued, in the eleventh and twelfth centuries, the European Middle Ages were in a 'constant process of translation,' of Roman, Germanic, and Celtic influences as well as Arabic and Hebrew ones, 'whose transformations and interactions to
14 R. Menendez Pidal and others have noted the parallels between Charles in the epic and Alphonse VI of Leon, who in the eleventh century also took refuge in the court of a Toledan emir and married a Muslim princess (Bancourt, 1982, 677-684). For a theory of the Arabic origins of names in the epic, see Warren (1929). 
15 On the alterity of southern European narrative and critical appropriations of the Islamic past, see Mallette (2010).

16 Fancy has argued that thirteenthcentury 'Aragonese kings asserted their aspirations to imperial authority not against but rather over and through the legacy of Almohads' (2013, 126).

17 For an account of just such a supersessionist strategy in the erasure of Jewish bodies and culture in the fourteenthcentury Alliterative Siege of Jerusalem, see Akbari (2012).

18 See Malo (2013) for a suggestive reconstruction of 'relic discourse' in late medieval English writing.

19 For an evocation of the different 'voices' that inscriptions upon objects can have and how these interact with their objects, see Karkov (2011, 135-178). this day have not been fully charted' (Stahuljak, 2004, 36). 'As if to minimize the fluctuation of these transfers and influences,' Stahuljak adds, the various meanings of medieval translatio are usually simplified as 'one movement from East to West, from Greece and Troy to Rome and France' (Stahuljak, 2004, 38). The concurrent, Arabo-Frankish translatio plotted by objects like Durendal usefully disrupts and fragments an otherwise distortedly unitary and unilinear account of imperial and cultural history. That some medieval Europeans, particularly southern Europeans, ${ }^{15}$ would see themselves as inheritors of imperium from contemporary Arabo-Islamic empires is unsurprising when we consider that Christian reconquest of previously Islamic lands in Sicily, Spain, and the Holy Land constitutes one of the dramatic historical narratives of the eleventh through thirteenth centuries, part of the wider and equally dramatic high medieval expansion of Europe tracked by Robert Bartlett and others (Bartlett, 1993). ${ }^{16}$ While according to a supersessionist account of such reconquest history, past Islamic imperium in newly Christianized lands would be deemed wholly quashed and therefore untraceable, ${ }^{17}$ according to a more inclusive and relativized view of translatio's operation, past imperial cultures may accrue and become visibly embedded in present forms without erasure, and triumphalism may cohabitate with expressions of preservation and homage towards the past in ways that trouble their distinction.

To 'think across' the disciplinary languages of translatio/n in literary and material studies is to realize their complementarity and indeed coproduction. The objects referenced in this study - swords, oliphants, honorific robes, and parasols - did not 'speak for themselves' but required the turn to a host of disciplinary materials and tools, from literary sources, to chronicles, images and sociological theory, before their symbolic meanings and distinctive language of power could be heard. ${ }^{18}$ Such 'encoding and decoding' of power is a form of 'translation' (Hunt, 1993, 297) that renders objects legible as texts (texts sometimes overlaid with more texts, such as inscriptions of previous owners or attached object itineraries). ${ }^{19}$ Other historical practices of object translation, like the visible, 'cumulative' layering of cultural borrowings seen in Ottonian works, express cultural processes with perhaps more immediacy and less need for reconstruction; but they, too, operate as metaphors that must ultimately be translated into language ('culminatio' or 'layering') in critical discussion. Such translation need not effect a flattening of the metaphorical force of the original object model: on the contrary, it is the distinctive physicality and visuality of cumulative spolia models, maintained in language like 'layering', that I have found especially suggestive for literary study. The enunciation of past borrowings has a way of attenuating supersessionist claims in favor of cumulative models. Chrétien de Troyes demonstrates as much in his famed prologue to Cligès, considered a locus classicus of the translatio topos, when he proclaims French cultural supersession over ancient Greeks and Romans about whom 'no one speaks any more' 
(Chrétien de Troyes, 1991, 123). ${ }^{20}$ That Chretien does continue to speak of these ancients forces us beyond the surface of his text to its deeper performance, one in which past cultural capital is embedded and accumulates within new imperial self-expression. Closer to the aims of this study, a multi-layered model encourages a three-dimensional approach to chansons de geste like Aspremont, leaving us better positioned to move beyond their surface pronouncements and to uncover within them symbolic exchanges and concurrent cultural genealogies of imperium otherwise effaced by the narrative of a medieval Europe of 'simple paternity' (Menocal, 1989, 498) and cultural patrimony.

\section{About the Author}

Shirin A. Khanmohamadi is an Associate Professor in Comparative and World Literature at San Francisco State University, where she specializes in premodern travel and ethnographic writing and medieval Mediterranean studies. She is the author of In Light of Another's Word: European Ethnography in the Middle Ages (University of Pennsylvania Press, 2014), and is now working on a book on the place of 'Saracens' in the translatio/n of empire and culture to Europe in chansons de geste and other genres (Email: shirin1@sfsu.edu).

\section{References}

Akbari, S.C. 2012. Erasing the body: History and Memory in Medieval Siege Poetry. In Remembering the Crusades: Myth, Image, and Identity, eds. N. Paul and S. Yeager. Baltimore, MD: The Johns Hopkins University Press.

Akbari, S.C. 2014. Embodying the Historical Moment: Tombs and Idols in the Histoire ancienne jusqu'à César. Journal of Medieval and Early Modern Studies 44(3): 617-43.

Bancourt, P. 1982. Les Musulman dans les chansons de geste du cycle du roi, 2 vols. AixMarseilles, France: Université de Provence.

Bartlett, R. 1993. The Making of Europe: Conquest, Colonization and Cultural Change, 950-1350. Princeton, NJ: Princeton University Press.

Block, R.H., et al., eds. 2014. Rethinking the New Medievalism. Baltimore, MD: The Johns Hopkins University Press.

Buc, P. 1997. Conversion of Objects: Suger of Saint-Denis and Meinwerk of Paderborn. Viator 28: 99-143.

Burns, E.J. 2002. Courtly Love Undressed: Reading Through Clothes in Medieval French Culture. Philadelphia, PA: University of Pennsylvania Press.

Campbell, E. and R. Mills, eds. 2012. Rethinking Medieval Translation: Ethics, Politics, Theory. Cambridge, UK: D.S. Brewer.

Catlos, B. 2015. Infidel Kings and Unholy Warriors. New York: Farrar, Straus, Giroux.
20 'Car des Grezois ne des Romains / Ne dit an mes ne plus ne mains, / D'ax est la parole remese/ Et estainte la vive brese.' (Chrétien de Troyes, 1975, lines 39-42). 
Chaganti, S. 2008. The Medieval Poetics of the Reliquary: Enshrinement, Inscription, Performance. New York: Macmillan.

Ch'ien, L. 2016. Local Alterity: Venice and its Peripatetic Saint. Paper Presented at the Medieval Association of the Pacific Conference: Medieval Cities: Crossroads in Time and Place. Davis, CA: March 30-April 2.

Chrétien de Troyes. 1975. Cligès, ed. A. Micha. Paris: Champion.

Chrétien de Troyes. 1991. Arthurian Romances, trans. W. Kibler. London: Penguin.

Copeland, R. 1991. Rhetoric, Hermeneutics, and Translation in the Middle Ages. Cambridge, UK: Cambridge University Press.

Everson, J. 2001. The Italian Romance Epic in the Age of Humanism. Oxford, UK: Oxford University Press.

Fancy, H. 2013. The Last Almohads: Universal Sovereignty between North Africa and the Crown of Aragon. Medieval Encounters 19: 102-136.

Flood, F.B. 2009. Objects of Translation: Material Culture and Medieval 'Hindu-Muslim' Encounter. Princeton, NJ: Princeton University Press.

Forsyth, I. 1995. Art with History: The Role of Spolia in the Cumulative Work of Art. In Byzantine East, Latin West: Art-Historical Studies in Honor of Kurt Weitzmann, ed. D. Mouriki, 153-58. Princeton, NJ: Princeton University Press.

French of Italy. 2017. Ed. L. Morreale. Fordham University Center for Medieval Studies. 18 May. https://frenchofitaly.ace.fordham.edu.

Geary, P. 1994. Living with the Dead in the Middle Ages. Ithaca, NY: Cornell University Press.

Georgopoulou, M. 1999. Orientalism and Crusader Art. Medieval Encounters 5(3): 289-321.

Gillingham, J. 2000. The English in the Twelfth Century. Rochester, NY: Boydell Press.

Grabar, O. 1997. Shared Culture of Objects. In Byzantine Court Culture from 829 to 1204, ed. H. Maguire, 115-129. Washington, DC: Dumbarton Oaks.

Grieve, P. 2009. The Eve of Spain: Myths of Origins in the History of Christian, Muslim and Jewish Conflict. Baltimore, MD: The Johns Hopkins University Press.

Hansen, M.F. 2003. The Eloquence of Appropriation: Prolegomena to an Understanding of Spolia in Early Christian Rome. Rome, Italy: 'L'Erma' di Bretschneider.

Hoffman, E. 2001. Pathways of Portability: Islamic and Christian Interchange from the Tenth to the Twelfth Century. Art History 24(1): 17-50.

Hunt, J.D. 1993. The Sign of the Object. In History from Things: Essays on Material Culture, eds. S. Lubar and W.D. Kingery, 293-98. Washington, DC and London: Smithsonian Institution Press.

Karkov, C.E. 2011. The Art of Anglo-Saxon England. Woodbridge, UK: Boydell.

Kinney, D. 2009. The Concept of Spolia. In A Companion to Medieval Art: Romanesque and Gothic in Northern Europe, ed. C. Rudolph, 233-252. Hoboken, NJ: WileyBlackwell.

Kinoshita, S. 2004. Almería Silk and the French Feudal Imaginary: Toward a 'Material' History of the Medieval Mediterranean. In Medieval Fabrications: Dress, Textiles, Clothwork, and Other Cultural Imaginings, ed. E.J. Burns, 165-176. New York: Palgrave Macmillan.

Kinoshita, S. 2006. Medieval Boundaries. Philadelphia, PA: University of Pennsylvania Press. 
Kinoshita, S. 2008. Translation, Empire, and the Worlding of Medieval Literature: The Travels of Kalila wa al-dimna. Postcolonial Studies 11(4): 371-85.

Kinoshita, S. 2012. Animals and the Medieval Culture of Empire. In Animal, Vegetable, Mineral: Ethics and Objects, ed. J.J. Cohen, 37-66. Washington, D.C.: Oliphaunt Books.

Knight, R. 2000. Stealing Stonehenge: Translation, Appropriation, and Cultural Identity in Robert Mannyng of Brunne's Chronicle. Journal of Medieval and Early Modern Studies 32(1): 41-58.

La Chanson d'Aspremont. 1919. Ed. L. Brandin. Paris, France: Honoré Champion.

La Chanson d'Aspremont [The Song of Aspremont]. 1989. Trans. M.A. Newth. Garland Library of Medieval Literature 61. New York: Garland.

La Chanson de Roland. 1922. Ed. J. Bédier. Paris, France: H. Piazza.

Mainet. 1875. Ed. G. Paris. Romania 4: 305-337.

Mallette, K. 2010. European Modernity and the Arab Mediterranean: Toward a New Philology and a Counter-Orientalism. Philadelphia, PA: University of Pennsylvania Press.

Malo, R. 2013. Relics and Writing in Late Medieval England. Toronto, ON: Toronto University Press.

Matthews, K.R. 2012. Plunder of War or Objects of Trade? The Reuse and Reception of Andalusi Objects in medieval Pisa. Journal of Iberian Studies 4(2): 233-58.

Menocal, M.R. 1989. Signs of the Times: Self, Other and History in Aucassin et Nicolette. Romanic Review 80(4): 497-511.

Perry, D.M. 2015. Sacred Plunder: Venice and the Aftermath of the Fourth Crusade. University Park, PA: Pennsylvania State University Press.

Renevey, D. and C. Whitehead, eds. 2009. Lost in Translation? The Medieval Translator/ Traduire au Moyen Âge 12. Turnhout, Belgium: Brepols.

Shalem, A. 2004. The Oliphant: Islamic Objects in Historical Context. Leiden, Netherlands: Brill.

Stahuljak, Z. 2004. An Epistemology of Tension. The Translator 10(1): 33-57.

Stahuljak, Z. 2005. Bloodless Genealogies of the French Middle Ages: Translatio, Kinship, and Metaphor. Gainesville, FL: University of Florida Press.

Sunderland, L. 2012. Multilingualism and Empire in L'Entrée d'Espagne. In Locating the Middle Ages: The Spaces and Places of Medieval Culture, ed. J. Weiss and S. Salih, 55-65. London: Center for Late Antique and Medieval Studies, King's College.

Virgil. 1983. Aeneid, trans. R. Fitzgerald. New York: Random House.

Wacks, D. 2014. Translation of Texts and Relics as Symbolic Capital in Caballero Zifar. La corónica 43(1): 115-40.

Walker, A. 2012. The Emperor and the World: Exotic Elements and the Imaging of Middle Byzantine Imperial Power, Ninth to Thirteenth Centuries C.E. Cambridge, UK: Cambridge University Press.

Warren, F.M. 1929. The Arabic Origin of 'Galafre,' 'Galienne,' and 'Orable.' Modern Philology 27(1): 23-26.

Waswo, R. 1995. Our Ancestors, the Trojans: Inventing Cultural Identity in the Middle Ages. Exemplaria 7(2): 269-90. 